\title{
IDENTIFIKASI FAKTOR-FAKTOR YANG MEMPENGARUHI EFISIENSI PERBANKAN SYARIAH INDONESIA
}

\author{
Yuliana Fitroh $^{1}$, Dikdik Harjadi ${ }^{2}$, Iqbal Arraniri ${ }^{3}$ \\ 1,2,3,Universitas Kuningan, Kabupaten Kuningan, Jawa Barat. \\ Corresponding author: $\underline{\text { iqbal @uniku.ac.id. }}$
}

Received: 01.06.2020

Revised: 18.06 .2020

Accepted: 25.06 .2020

\begin{abstract}
This study was done due to provide empirical facts from the effect of Financing to Deposit Ratio (FDR), Non Performing Financing (NPF), Bank Size, Gross Domestic Product (GDP), and Inflation on the efficiency of Indonesian Islamic Banking. This study used secondary data from the annual financial statements of Islamic Banks, with verification research methods. To measure efficiency this study used the Data Envelopment Analysis (DEA) method with DEAP software version 21. The research sample was determined by using purposive sampling technique. The sample selected was 12 General Islamic Banking. The period used 2014 to 2018. Analysis of the data used is regression analysis panel data with Eviews Version 10. Based on the results of efficiency measurements of 12 General Islamic Banking shows a fluctuating trend, and only one General Islamic Banking experiences efficient conditions throughout the research period, while the results of the hypothesis analysis be concluded that FDR and Bank Size have a significant positive effect, while NPF, GDP, and Inflation have a significant negative effect on the efficiency of Islamic Banking.
\end{abstract}

Keywords: Bank Size ; Efficiency ; FDR ; GDP ; Inflation ; NPF

\begin{abstract}
Abstrak.
Penelitian ini dilakukan untuk membuktikan fakta empiris dari pengaruh Financing to Deposit Ratio (FDR), Non Performing Financing (NPF), Bank Size (Ukuran Bank), Gross Domestic Product (GDP), dan Inflasi terhadap efisiensi perbankan syariah Indonesia. Penelitian ini menggunakan data sekunder dari laporan keuangan tahunan bank syariah, dengan metode penelitian verifikatif. Untuk pengukuran efisiensi menggunakan metode Data Envelopment Analysis (DEA) dengan bantuan software DEAP Version 21. Sampel penelitian ditentukan menggunakan teknik purposive sampling. Sampel yang terpilih sebanyak 12 Bank Umum Syariah. Periode yang digunakan tahun 2014 sampai 2018. Analisis data yang digunakan adalah analisis regresi data panel dengan bantuan Eviews Version 10. Berdasarkan hasil pengukuran efisiensi dari 12 Bank Umum Syariah menunjukkan trend yang berfluktuatif, dan hanya satu Bank Umum Syariah yang mengalami kondisi efisien sepanjang periode penelitian, sedangkan hasil pengujian hipotesis disimpulkan bahwa FDR dan Bank Size berpengaruh positif signifikan, sedangkan NPF, GDP, dan Inflasi berpengaruh negatif signifikan terhadap efisiensi perbankan syariah.
\end{abstract}

Katakunci: Ukuran Bank, Efisiensi, FDR, GDP, Inflasi, NPF 


\section{PENDAHULUAN}

Sejak diberlakukannya Dual System bank di Indonesia melalui undang-undang perbankan No. 10 tahun 1998 [1] dan undang-undang No. 21 tahun 2008 [2], perkembangan perbankan syariah menunjukkan pertumbuhan yang cukup baik dalam hal kelembagaan, tercatat menurut data statistik perbankan syariah yang dipublikasikan oleh Otoritas Jasa Keuangan (OJK) [3] sampai tahun 2018 jumlah bank syariah di Indonesia mencapai 14 Bank Umum Syariah (BUS), 20 Unit Usaha Syariah (UUS), dan 167 Bank Pembiayaan Rakyat Syariah (BPRS), jumlahnya mengalami peningkatan dari tahun 2014 yang hanya berjumlah 12 BUS, 22 UUS, dan 163 BPRS. Akan tetapi peningkatan pertumbuhan perbankan syariah ini tidak diiringi dengan meningkatnya efisiensi dari bank syariah, atau tidak diiringi dengan menurunnya rasio BOPO (Biaya Operasional terhadap Pendapatan Operasional), karena menurut ukuran efisiensi dapat dilihat dari rasio BOPO, semakin tinggi rasio BOPO maka bank tersebut semakin tidak efisien. Sedangkan untuk ketentuan batasan rasio BOPO bagi bank umum diantaranya bagi Bank Umum Kegiatan Usaha (BUKU) 3 dan 4 maksimal rasio BOPO yaitu sebesar 75\%, sedangkan untuk BUKU 1 dan 2 maksimal rasio BOPO yaitu sebesar 85\%. Menurut OJK dalam statistik perbankan syariah sampai saat ini mayoritas BUS berada di BUKU 1 dan 2 karena rata-rata modal inti yang dimiliki masih kurang dari lima triliyun rupiah. Namun faktanya batasan rasio BOPO tersebut masih belum dimaksimalkan oleh bank syariah, karena BUS di Indonesia ratarata masih memiliki tingkat rasio BOPO yang tinggi, terlihat dari tabel berikut ini :

Tabel 1.

Perkembangan Tingkat Rasio BOPO BUS tahun 2014-2018

\begin{tabular}{|c|c|c|c|c|c|}
\hline Tahun & 2014 & 2015 & 2016 & 2017 & 2018 \\
\hline Rasio BOPO (\%) & 96,97 & 97,01 & 96,22 & 94,91 & 89,18 \\
\hline
\end{tabular}

Sumber: OJK (Statistika Perbankan Syariah Indonesia 2014-2018)[3]

Tabel 1 menunjukan perkembangan tingkat rasio BOPO BUS Indonesia, terlihat perkembangannya mengalami penurunan dari tahun 2015 sampai tahun 2018, menurunnya tingkat rasio BOPO BUS bukan berarti bank tersebut telah bekerja secara efisien, karena dapat diketahui hingga tahun 2018 tingkat rasio BOPO BUS masih berada diatas batasan maksimal rasio BOPO yang ditentukan oleh OJK pada BUKU 1 dan 2 yaitu sebesar 85\%, maka dari itu dapat disimpulkan bahwa sampai saat ini perbankan syariah di Indonesia khususnya BUS masih belum mencapai kinerja yang efisien. Menurut Firdaus dan Hosen [4], pengukuran efisiensi dapat menjadi suatu indikator penting untuk melihat kemampuan bank untuk bertahan, karena dalam proses pertumbuhan industri perbankan syariah perlu dilakukannya pengukuran efisiensi 
untuk melihat kemampuan bank syariah dalam menghadapi ketatnya persaingan pada industri perbankan syariah dan industri perbankan nasional di Indonesia, dan juga untuk mengetahui kemampuan dalam memperluas pangsa pasarnya. Sedangkan jika pengukuran efisiensi perbankan syariah dibiarkan, maka akan berdampak pada menurunnya tingkat profitabilitas suatu bank, hal tersebut diperkuat oleh pendapat Muharam [5] yang menjelaskan bahwa analisa efisiensi perbankan syariah penting untuk dilakukan karena penghimpunan dan penyaluran pembiayaan yang ekspansif tanpa memperhatikan faktor efisiensi akan berpengaruh terhadap profitabilitas suatu bank. Berdasarkan beberapa penelitian yang telah dilakukan mengenai faktor-faktor yang mempengaruhi efisiensi perbankan syariah, umumnya menjelaskan bahwa faktor-faktor tesebut adalah faktor internal dan faktor eksternal, beberapa penelitian yang telah dilakukan baik mengenai pengaruh faktor internal dan juga eksternal terhadap efisiensi bank menunjukkan hasil yang bervariasi dari peneliti satu dengan peneliti yang lainnya, faktor yang digunakan dalam penelitian tersebut diantaranya menggunakan faktor internal seperti Financing to Deposit Ratio (FDR), Non Peforming Financing (NPF), Bank Size, dan untuk faktor eksternal diantaranya Gross Domestic Product (GDP) dan Inflasi. Beberapa peneliti yang telah melakukan penelitiannya mengenai pengaruh NPF terhadap efisiensi perbankan syariah, menunjukkan hasil yang bervariasi atau tidak sama antara peneliti yang satu dan yang lainnya. Hasil penelitian yang dilakukan oleh Pambuko [6] menyatakan bahwa NPF memiliki pengaruh positif dan signifikan atau dengan kata lain semakin banyak pembiayaan macet, maka BUS akan semakin efisien. Sementara hasil penelitian yang dilakukan Wahab [7], menyatakan bahwa NPF berpengaruh negatif tidak signifikan terhadap efisiensi bank syariah dengan pendekatan SFA. Hasil tersebut sejalan dengan hasil penelitian yang dilakukan oleh Firdaus dan Hosen [4] yang menunjukkan bahwa NPF memiliki pengaruh negatif dan signifikan terhadap efisiensi perbankan syariah Indonesia. Semakin besar nilai NPF pada suatu bank maka secara otomatis akan mengganggu kegiatan operasional bank, terutama dari segi likuiditas bank tersebut. Maka hal tesebut akan menyebabkan suatu bank menjadi inefisien dalam mendayagunakan seluruh sumber daya yang dimiliki. Sufian dan Kamarudin [8] menyatakan bahwa bank size memiliki hubungan yang positif dengan efisiensi bank, serta menurut Firdaus dan Hosen [4] yang menyatakan bahwa aset berpengaruh positif dan signifikan, karena dengan jumlah aset yang besar suatu perusahaan dapat lebih leluasa menjalankan kegiatan operasionalnya dan mencapai optimalisasi sumber daya yang dimilikinya. Tetapi berbeda dengan penelitian yang dilakukan oleh Batir dkk [9] yang menyatakan bahwa Bank Size berpengaruh negatif signifikan terhadap efisiensi perbankan. Hasil penelitian yang dilakukan oleh Akhtar [10] menunjukkan bahwa kondisi ekonomi yang sedang tumbuh membuat bank 
semakin efisien. Sementara Repkova [11] menjelaskan bahwa pertumbuhan GDP memiliki pengaruh negatif dan signifikan, GDP yang lebih tinggi cenderung menarik investor untuk mendirikan bank baru, baik bank lokal baru atau bank asing baru, dengan demikian persaingan akan semakin tinggi. Bank yang beroperasi di negara-negara yang memiliki pertumbuhan (Produk Domestik Bruto) PDB lebih tinggi cenderung bersaing dengan bank lain yang akan menghasilkan margin laba yang lebih kompetitif. Hasil tersebut juga sejalan dengan hasil penelitian yang dilakukan oleh Batir dkk [9] dan Pambuko [6] yang menjelaskan bahwa adanya pengaruh negatif antara pertumbuhan GDP dengan efisiensi perbankan. Dari penjelasan tersebut, maka peneliti akan meneliti mengenai faktor-faktor yang mempengaruhi efisiensi perbankan syariah. Penelitian ini dilakukan untuk menganalisis efisiensi dari masing-masing BUS yang ada di Indonesia pada periode 2014-2018, serta untuk menguji kembali dari adanya perbedaan pendapat antara peneliti terdahulu khususnya mengenai pengaruh NPF, Bank Size, dan GDP terhadap efisiensi perbankan syariah.

\section{KAJIAN LITERATUR}

\section{Agency Theory}

Agency Theory diartikan sebagai hubungan keagenan (agency relationship) dari sebuah kontrak antara pemberi wewenang atau pemilik (principal) dengan yang diberi wewenang atau manager (agent) untuk memberikan kemampuannya dengan mendapatkan beberapa kewenangan dalam pengambilan keputusan [12]. Agency relationship dapat timbul dan berkembang dari sebuah perusahaan yang mengalami perubahan dalam kepemilikan, sehingga dapat menyebabkan pemisahan antara kepemilikan dan pengawasan. Inilah yang menjadi sumber dari masalah keagenan (agency problem). Manajer sebagai agent berkewajiban untuk memberikan kontribusi semaksimal mungkin terhadap principal, namun disisi lain manajer juga berusaha untuk memaksimalkan kepentingan pribadinya. Adanya asimetri informasi (information asymmetry) disebabkan agent mempunyai informasi yang lebih banyak atas prospek perusahaan jika dibandingkan dengan principal.

Agency theory mencoba mengurangi agency problem yang muncul akibat adanya kontrak principal dan agent antara corporate governance dengan kinerja perusahaan. Agency problem dapat diatasi dengan pemberian insentif dan membuat mekanisme monitoring. Dalam hal ini, industri perbankan di Indonesia merupakan jenis usaha yang harus selalu dalam pengawasan pemerintah, karena bank sebagai agent of development yang artinya tanpa adanya bank maka dapat dipastikan pertumbuhan ekonomi akan sangat lambat dan bahkan menjadi stagnan karena fungsi utama bank sebagai intermediasi antara pemilik dana dan pihak yang memerlukan dana 
untuk perputaran usahanya. Sehingga di dalam suatu pemerintah demokrasi, hubungan antara pemerintah dan masyarakat dapat digambarkan sebagai hubungan keagenan (agency relationship) [13].

\section{Bank Syariah}

Bank syariah adalah bank yang menjalankan kegiatan usahanya berdasarkan prinsipprinsip syariah dan menurut jenisnya terdiri atas Bank Umum Syariah, Unit Usaha Syariah, dan Bank Pembiayaan Rakyat Syariah [14].

\section{Efisiensi Perbankan Syariah}

Efisiensi didefinisikan sebagai perbandingan antara keluaran (output) dengan masukan (input). Suatu perusahaan dapat dikatakan efisien jika perusahaan tersebut dapat menghasilkan output yang lebih besar jika dibandingkan perusahaan lain dengan mempergunakan jumlah input yang sama. Atau menghasilkan jumlah output yang sama, tetapi jumlah input yang dipergunakan lebih sedikit dibandingkan jumlah input yang digunakan perusahan lain. Dengan demikian, ada tiga faktor yang menyebabkan efisiensi, pertama apabila dengan input yang sama dapat menghasilkan output yang lebih besar, kedua dengan input yang lebih kecil dapat menghasilkan output yang sama, yang ketiga dengan input yang lebih besar dapat menghasilkan jumlah output dengan persentase yang lebih [15]. Hamidi dan Lisnawati [16] berpendapat bahwa operasional bisnis efisien apabila total pengeluaran masih di bawah total pendapatan.

PBI No.9/1/PBI/2007 menyatakan bahwa, tingkat kesehatan bank adalah hasil penilaian kualitatif maupun kuantitatif atas berbagai faktor yang berpengaruh terhadap kondisi atau kinerja suatu bank. Faktor-faktor tersebut antara lain, permodalan, kualitas aset, rentabilitas, likuiditas, sensitivitas terhadap resiko pasar dan faktor manajemen. Secara empiris hasil dari penelitian terdahulu dapat disimpulkan faktor- faktor yang diduga berpengaruh terhadap efisiensi antara lain ROA, ROE, CAR, NPF, KAP, BOPO, FDR, NIM, GCG, Kapitalisasi, Bank Size, jumlah cabang bank dan beban bagi hasil. Serta faktor dari luar antara lain, GDP, Inflasi, dan Kurs.

Efisiensi bank merupakan salah satu indikator penting untuk menganalisis kinerja suatu bank, selain itu juga sebagai sarana untuk dapat meningkatkan efektifitas kebijakan moneter [17]. Menurut Muharam [5] ada tiga jenis pendekatan pengukuran efisiensi khususnya perbankan yaitu:

1. Pendekatan Rasio

Pendekatan rasio ini dalam mengukur efisiensi dilakukan dengan cara menghitung perbandingan output dan input yang digunakan. Pendekatan ini akan dapat dinilai 
memiliki efisiensi yang tinggi apabila dapat menghasilkan output yang semaksimal mungkin dengan input yang seminimal mungkin.

$$
\text { efisiensi }=\frac{\text { Output }}{\text { Input }}
$$

2. Pendekatan Regresi

Pendekatan ini dalam mengukur efisiensi menggunakan sebuah model dari tingkat output tertentu sebagai fungsi dari berbagai tingkat input tertentu. Fungsi regresi adalah sebagai berikut:

$\mathrm{Y}=f(X 1, X 2, X 3, X 4, \ldots \ldots \ldots . . . X n)$

Dimana:

$\mathrm{Y}=$ Output

$\mathrm{X}=$ Input

Pendekatan regresi akan menghasilkan estimasi hubungan yang dapat digunakan untuk memproduksi tingkat output yang dihasilkan sebuah Unit Kegiatan Ekonomi (UKE) pada tingkat input tertentu. UKE dapat dikatakan efisien apabila menghasilkan output lebih banyak dari pada output hasil estimasi.

3. Pendekatan Frontier

Pendekatan frontier dalam mengukur efisiensi dibedakan menjadi dua jenis yaitu frontier parametrik (parametric approach) dan frontier non parametrik (non parametric approach). Tes parametrik adalah tes yang modelnya menetapkan adanya syarat-syarat tertentu tentang parameter populasi yang merupakan sumber penelitiannya, diantaranya ada Stochastic Frontier Approach (SFA), Thick Frontier Approach (TFA), dan Distributtion Free Approach (DFA). Sedangkan tes non parametrik adalah tes yang modelnya tidak menetapkan syarat-syarat mengenai parameter populasi yang merupakan induk sampel penelitiannya, diantaranya ada Data Envelopment Analysis (DEA) dan Free Disposable Hull (FDH).

Pengukuran efisiensi pada penelitian ini menggunakan tes non parametrik dengan teknik DEA yang merupakan teknik menghitung efisiensi untuk seluruh unit bank-bank syariah dan merupakan prosedur dirancang khusus untuk mengukur efisiensi yang menggunakan banyak input dan banyak output, dimana penggabungan input dan output tersebut tidak dapat dilakukan. Nilai efisiensi dari DEA relatif tergantung pada nilai efisiensi dari unit-unit bank syariah lain didalam sampel. DEA juga mampu memberikan rekomendasi faktor-faktor apa saja yang harus dilakukannya perubahan untuk mencapai nilai efisiensi [18]. DEA dilakukan untuk membandingkan efisiensi antar satu bank dengan bank yang lainnya, sedangkan untuk rasio 
BOPO hanya digunakan untuk mengetahui efisiensi dari perbankan saja [13]. Menurut Ada dan Dalkinic dalam Hidayati dkk [19] nilai efisiensi berkisar dari 0 sampai 1, semakin mendekati 1 maka semakin efisien kinerja dari bank tersebut.

Terdapat dua model yang sering digunakan dalam pendekatan DEA yaitu model Charnes, Chooper, dan Roodes (CCR) dan model Banker, Charnes, dan Cooper (BCC). Model DEA CCR dikenal dengan CRS (Constant Return to Scale) dimana penambahan input sebesar n kali akan meningkatkan output sebesar n kali. Model DEA BCC atau VRS (Variable Return to Scale) mengasumsikan bahwa setiap penambahan satu unit input tidak berarti diikuti dengan penambahan satu unit output, penambahan outputnya bisa lebih besar dari pada satu atau kurang dari satu (Coelli, dkk, 2005 dalam Pambuko [6]). Berkaitan dengan input dan output yang digunakan dalam pengukuran efisiensi perbankan, terdapat tiga pendekatan yang digunakan yaitu pendekatan aset, pendekatan produksi, dan pendekatan intermediasi [6].

Pada penelitian ini, pengukuran efisiensi menggunakan teknik Data Envelopment Analysis (DEA) dilakukan berorientasi pada output oriented dengan menggunakan asumsi VRS, karena dianggap lebih tepat jika digunakan untuk menganalisis efisiensi kinerja pada perusahaan jasa, karena faktor seperti sumber daya manusia lebih signifikan perannya jika dibandingkan dengan faktor lainnya, seperti kas, modal, dan lain-lain. Dalam penentuan input dan output yang digunakan untuk mengukur efisiensi perbankan syariah akan menggunakan pendekatan intermediasi, dimana bank memiliki fungsi untuk menghimpun dan menyalurkan dana. Adapun unit input dan output yang digunakan adalah sebagai berikut:

1. Unit Input

1) Dana Pihak Ketiga (DPK) merupakan dana yang dihimpun oleh bank yang berasal dari masyarakat dalam arti luas, meliputi masyarakat individu maupun badan usaha [20].

2) Biaya Tenaga Kerja (BTK)

Merupakan harga atau jumlah rupiah tertentu yang dibayarkan kepada para pekerja atau karyawan yang bekerja pada bagian produksi [21].

2. Unit Output

1) Pembiayaan

Merupakan penjumlahan daripada seluruh pembiayaan yang diberikan oleh bank syariah, terdiri dari pembiayaan murabahah, mudharabah, musyarakah, istishna, dan qardhul hasan [15].

2) Pendapatan Operasional 
Merupakan pendapatan bank yang diperoleh dari usaha pokok bank yang meliputi pendapatan bunga, provisi, komisi dan fee, dan pendapatan valuta asing [22].

Hidayati, dkk [19] menjelaskan persamaan secara umum pada DEA sebagai berikut :

$$
h_{s}=\frac{\sum_{i=1}^{m} u_{i} y_{i s}}{\sum_{j}^{n} v_{j} x_{j s}}
$$

Dimana:

$h s$ : Efisiensi masing-masing bank syariah

$m:$ Jumlah output bank syariah yang diamati

$n$ : Jumlah input bank Syariah yang diamati

$y i s$ : Jumlah output $i$ yang dihasilkan dari masing-masing bank syariah

$x j$ : Jumlah input $j$ yang digunakan masing-masing bank syariah

$u i$ : Bobot output $i$ yang dihasilkan per bank syariah

$v j$ : Bobot input $j$ yang dihasilkan per bank syariah

\section{Financing to Deposit Ratio (FDR)}

Dendawijaya [23] menjelaskan bahwa FDR adalah ukuran seberapa jauh kemampuan bank dalam membiayai kembali penarikan dana yang dilakukan deposan dengan mengandalkan pembiayaan yang diberikan sebagai sumber likuiditasnya, dan perhitungan FDR dapat dirumuskan sebagai berikut :

$$
\mathrm{FDR}=\frac{\text { Total Pembiayaan }}{\text { Total Dana Pihak Ketiga (DPK) }} \times 100 \%
$$

FDR mencerminkan mengenai besarnya pembiayaan yang disalurkan dari dana yang telah dihimpun dari masyarakat. Pambuko [6] dalam penelitiannya menjelaskan bahwa semakin besar porsi DPK yang dialokasikan untuk pembiayaan akan menyebabkan BUS semakin efisien dalam mengelola sumberdayanya. Lebih lanjut, hasil ini juga sesuai dengan hasil analisis DEA yang mengungkapkan bahwa salah satu penyebab ketidakefisienan bank syariah adalah kurangnya jumlah pembiayaan yang dialokasikan kepada masyarakat sehingga jika jumlah pembiayaan ditingkatkan, maka akan membuat bank semakin efisien.

\section{Non Performing Financing (NPF)}

Wangsawidjaja [24] menjelasakan NPF atau pembiayaan bermasalah adalah pembiayaan yang kualitasnya berada dalam golongan kurang lancar, diragukan, dan macet. Perhitungan NPF dapat dirumuskan sebagai berikut:

$$
N P F=\frac{\text { Pembiayaan Bermasalah }}{\text { Total Pembiayaan }} X 100 \%
$$


NPF yang tinggi akan memperbesar biaya sehingga berpotensi terhadap kerugian bank. Semakin tinggi rasio ini maka akan semakin buruk kualitas kredit bank yang menyebabkan jumlah kredit bermasalah semakin besar, dan oleh karena itu bank harus menanggung kerugian dalam kegiatan operasionalnya sehingga berpengaruh terhadap penurunan laba yang diperoleh bank [6]. Semakin besar nilai NPF pada suatu bank maka secara otomatis akan mengganggu kegiatan operasional bank, terutama dari segi likuiditas bank tersebut. Maka hal tesebut akan menyebabkan suatu bank menjadi inefisien dalam mendayagunakan seluruh sumber daya yang dimiliki [4].

\section{Bank Size}

Menurut Ardi dan Lana [25], Ukuran bank didefinisikan sebagai ukuran besar kecilnya suatu bank tersebut. Ukuran bank dapat dinyatakan dalam total aktiva, penjualan, dan kapitalisasi. Semakin besar penjualan, aktiva, dan kapitalisasi pasar maka semakin besar pula ukuran perusahaan itu. Besar kecilnya perusahaan dapat dilihat dari total asset yang dimiliki perusahaan tersebut. Semakin besar asset yang dimiliki perusahaan maka semakin besar pula ukuran perusahaan tersebut. Perhitungan bank size tersebut dirumuskan sebagai berikut:

$$
\text { Bank Size }=\text { Ln (Total Assets) }
$$

Dengan jumlah aset yang besar suatu perusahaan dapat lebih leluasa menjalankan kegiatan operasionalnya dan mencapai optimalisasi sumber daya yang dimilikinya. mempunyai pengaruh yang positif terhadap efisiensi perbankan syariah [4].

\section{Gross Domestic Product (GDP)}

GDP adalah nilai pasar dari semua barang dan jasa akhir (final) yang diproduksi dalam sebuah negara pada suatu periode [26]. Menurut Mankiw [26], komponen - komponen dari GDP dapat diuraikan dalam persamaan sebagai berikut :

$$
\mathrm{Y}=\mathrm{C}+\mathrm{I}+\mathrm{G}+\mathrm{NX}
$$

Dimana: $\mathrm{Y}=$ GDP

$$
\begin{array}{ll}
\mathrm{C} & =\text { Konsumsi }(\mathrm{C}) \\
\mathrm{I} & =\text { Investasi, belanja negara } \\
\mathrm{G} & =\text { Belanja Negara } \\
\mathrm{NX} & =\text { Ekspor Netto }
\end{array}
$$

GDP yang lebih tinggi cenderung menarik investor untuk mendirikan bank baru, baik bank lokal baru atau bank asing baru, dengan demikian persaingan akan semakin tinggi. Bank yang beroperasi di negara-negara yang memiliki pertumbuhan (Produk Domestik Bruto) PDB 
lebih tinggi cenderung bersaing dengan bank lain yang akan menghasilkan margin laba yang lebih kompetitif [11].

\section{Inflasi}

Inflasi adalah kecenderungan meningkatnya harga barang dan jasa secara umum dan terus menerus [27]. Menurut M. Natsir [27] penghitungan inflasi dapat digunakan menghitung Indeks Harga Konsumen (IHK). IHK merupakan ukuran perubahan harga dari kelompok barang dan jasa yang jumlah kuantitasnya sering dikonsumsi oleh rumah tangga dalam rentang waktu tertentu. Adapun secara sistematis dapat dirumuskan sebagai berikut :

$$
\text { Inflasi }=\frac{\mathrm{IHK}_{n}-\mathrm{IHK}_{n-1}}{\mathrm{IHK}_{n-1}} \times 100 \%
$$

Keterangan :

IHKn : Indeks Harga Konsumen Tahun ke-n

IHKn-1:Indeks Harga Konsumen pada Tahun Sebelumnya (n-1)

Tingkat inflasi yang tinggi mempengaruhi ekonomi dan kinerja industri keuangan. Kenaikan harga barang dan jasa secara tidak langsung dapat meningkatkan biaya operasional sektor perbankan, yang kemudian akan menurunkan efisiensi perbankan syariah.

\section{Hubungan Antar Variabel}

Pambuko [6] dalam penelitiannya menjelaskan bahwa FDR berpengaruh positif dan signifikan terhadap efisiensi perbankan syariah, dengan kata lain semakin besar porsi DPK yang dialokasikan untuk pembiayaan akan menyebabkan BUS semakin efisien dalam mengelola sumberdayanya. Lebih lanjut, hasil ini juga sesuai dengan hasil analisis DEA yang mengungkapkan bahwa salah satu penyebab ketidakefisienan bank syariah adalah kurangnya jumlah pembiayaan yang dialokasikan kepada masyarakat sehingga jika jumlah pembiayaan ditingkatkan, maka akan membuat bank semakin efisien.

Semakin tinggi rasio NPF maka akan semakin buruk kualitas kredit bank yang menyebabkan jumlah kredit bermasalah semakin besar, dan oleh karena itu bank harus menanggung kerugian dalam kegiatan operasionalnya sehingga berpengaruh terhadap penurunan laba yang diperoleh bank Pambuko [6]. Dalam penelitian yang dilakukan Firdaus dan Hosen [4] yang menunjukkan bahwa NPF memiliki pengaruh negatif dan signifikan terhadap efisiensi perbankan syariah Indonesia. Semakin besar nilai NPF pada suatu bank maka secara otomatis akan mengganggu kegiatan operasional bank, terutama dari segi likuiditas bank tersebut. Maka hal tesebut akan menyebabkan suatu bank menjadi inefisien dalam mendayagunakan seluruh sumber daya yang dimiliki. 
Dalam penelitian yang dilakukan oleh Firdaus dan Hosen [4] yang menyatakan bahwa aset berpengaruh positif dan signifikan, karena dengan jumlah aset yang besar suatu perusahaan dapat lebih leluasa menjalankan kegiatan operasionalnya dan mencapai optimalisasi sumber daya yang dimilikinya.

Hasil penelitian yang dilakukan oleh Repkova [11] menjelaskan bahwa pertumbuhan GDP memiliki pengaruh negatif dan signifikan, GDP yang lebih tinggi cenderung menarik investor untuk mendirikan bank baru, baik bank lokal baru atau bank asing baru, dengan demikian persaingan akan semakin tinggi. Bank yang beroperasi di negara-negara yang memiliki pertumbuhan (Produk Domestik Bruto) PDB lebih tinggi cenderung bersaing dengan bank lain yang akan menghasilkan margin laba yang lebih kompetitif. Hasil tersebut juga sejalan dengan hasil penelitian yang dilakukan oleh Batir dkk [9], Pambuko [6] yang menjelaskan bahwa adanya pengaruh negatif dan signifikan antara pertumbuhan GDP dengan efisiensi perbankan.

Tingkat inflasi yang tinggi mempengaruhi ekonomi dan kinerja industri keuangan. Kenaikan harga barang dan jasa secara tidak langsung dapat meningkatkan biaya operasional sektor perbankan, yang kemudian akan menurunkan efisiensi perbankan syariah [28].

Dengan demikian hubungan antar variabel bebas dan variabel terikat dapat digambarkan dalam paradigma penelitian berikut ini:

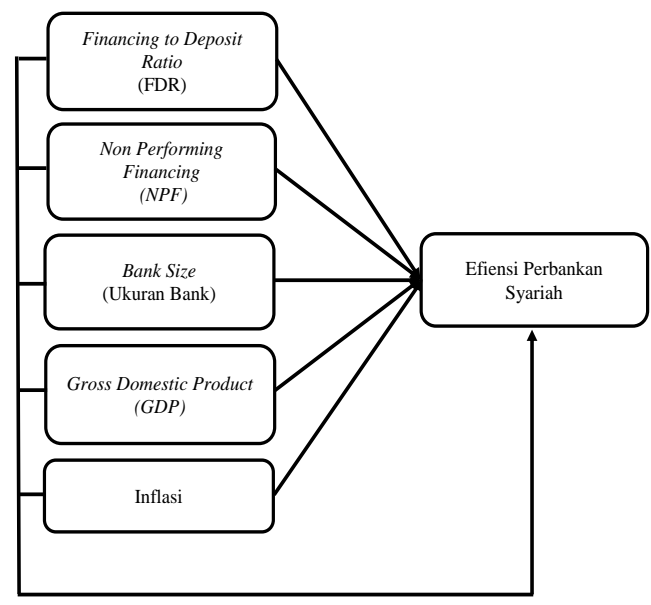

Gambar 1

Paradigma Penelitian

\section{Hipotesis}

Menurut Sugiyono [29] hipotesis adalah jawaban sementara terhadap permasalahan rumusan masalah penelitian. Maka rumusan hipotesis dapat dirumuskan sebagai berikut : 
H1 Financing to Deposit Ratio (FDR), Non Performing Financing (NPF), Bank Size (Ukuran Bank), Gross Domestic Product (GDP), dan Inflasi secara simultan berpengaruh terhadap efisiensi perbankan syariah.

H2 Financing to Deposit Ratio (FDR) secara parsial berpengaruh terhadap efisiensi perbankan syariah.

H3 Non Performing Financing (NPF) secara parsial berpengaruh terhadap efisiensi perbankan syariah.

H4 Bank Size (Ukuran Bank) secara parsial berpengaruh terhadap efisiensi perbankan syariah.

H5 Gross Domestic Product (GDP) secara parsial berpengaruh terhadap efisiensi perbankan syariah.

H6 Inflasi secara parsial berpengaruh terhadap efisiensi perbankan syariah.

\section{METODE PENELITIAN}

Pada penelitian ini penulis menggunakan metode verifikatif dengan pendekatan kuantitatif. Menurut Sugiyono [29] metode penelitian verifikatif adalah suatu penelitian yang ditujukan untuk menguji teori dan akan mencoba menghasilkan metode ilmiah yakni status hipotesa yang berupa kesimpulan, apakah suatu hipotesa diterima atau ditolak.

\section{Operasional Variabel}

Menurut Sugiyono [29] variabel penelitian adalah suatu atribut atau sifat atau nilai dari orang, objek, atau kegiatan yang mempunyai variasi tertentu yang ditetapkan oleh peneliti untuk dipelajari dan ditarik kesimpulan. Variabel yang digunakan dalam penelitian ini yaitu sebagai berikut :

\section{Variabel Dependen}

Variabel dependen adalah variabel yang dipengaruhi atau yang menjadi akibat, karena adanya variabel bebas [29]. Variabel dependen atau Variabel Y dalam penelitian ini adalah efisiensi perbankan syariah, yang nilai ukurnya diperoleh dari hasil pengukuran efisiensi perbankan syariah dengan metode pengukuran Data Envelopment Analysis (DEA). Efisiensi bank merupakan salah satu indikator penting untuk menganalisis kinerja suatu bank, selain itu juga sebagai sarana untuk dapat meningkatkan efektifitas kebijakan moneter [17]. Pengukuran efisiensi bank menggunakan DEA dapat dirumuskan dalam persamaan sebagai perikut : 


$$
h_{s}=\frac{\sum_{i=1}^{m} u_{i} y_{i s}}{\sum_{j}^{n} v_{j} x_{j s}}
$$

Skala yang digunakan pada variabel efisiensi bank yaitu skala rasio.

2. Variabel Independen

Variabel independen adalah variabel yang mempengaruhi atau yang menjadi sebab perubahannya atau timbulnya variabel dependen [29]. Variabel independen atau variabel $\mathrm{X}$ dalam penelitian ini yaitu:

1) Financing to Deposit Ratio (FDR) (X1), adalah ukuran seberapa jauh kemampuan bank dalam membiayai kembali penarikan dana yang dilakukan deposan dengan mengandalkan pembiayaan yang diberikan sebagai sumber likuiditasnya [23]. Pengukuran FDR dapat dirumuskan dalam persamaan sebagai berikut :

$$
\text { FDR }=\frac{\text { Total Pembiayaan }}{\text { Total Dana Pihak Ketiga (DPK) }} X 100 \%
$$

Skala yang digunakan pada variabel FDR yaitu skala rasio.

2) Non Performing Financing (NPF) (X2), atau biasa disebut pembiayaan bermasalah adalah pembiayaan yang kualitasnya berada dalam golongan kurang lancar, diragukan, dan macet [24]. Pengukuran NPF dapat dirumuskan dalam persamaan sebagai berikut :

$$
N P F=\frac{\text { Pembiayaan Bermasalah }}{\text { Total Pembiayaan }} X 100 \%
$$

Skala yang digunakan pada variabel NPF yaitu skala rasio.

3) Bank Size (Ukuran Bank) (X3), didefinisikan sebagai ukuran besar kecilnya suatu bank tersebut [25]. Pengukuran bank size dapat dirumuskan dalam persamaan sebagai berikut:

$$
\text { Bank Size = Ln (Total Assets) }
$$

Skala yang digunakan pada variabel bank size yaitu skala rasio.

4) Gross Domestic Product (GDP) (X4), adalah nilai pasar dari semua barang dan jasa akhir (final) yang diproduksi dalam sebuah negara pada suatu periode [26]. Pengukuran GDP dapat dirumuskan dalam persamaan sebagai berikut :

$$
\mathrm{Y}=\mathrm{C}+\mathrm{I}+\mathrm{G}+\mathrm{NX}
$$

Skala yang digunakan pada variabel GDP yaitu skala rasio.

5) Inflasi (X5), adalah kecenderungan meningkatnya harga barang dan jasa secara umum dan terus menerus [27]. Pengukuran inflasi dapat dirumuskan dalam persamaan sebagai berikut : 


$$
\text { Inflasi }=\frac{\mathrm{IHK}_{n}-\mathrm{IHK}_{n-1}}{\mathrm{IHK}_{n-1}} \times 100 \%
$$

Skala yang digunakan pada variabel inflasi yaitu skala rasio.

\section{Populasi dan Sampel}

Populasi yang digunakan pada penelitian ini yaitu Bank Umum Syariah (BUS) yang terdaftar di OJK sebanyak 14 BUS dan tidak semua populasi ini akan menjadi objek penelitian, sehingga perlu dilakukannya pengambilan sampel lebih lanjut. Teknik penentuan sampel dalam penelitian ini adalah dengan menggunakan purposive sampling. Purposive sampling adalah teknik penentuan sampel dengan pertimbangan tertentu [29]. Alasan pemilihan sampel dengan menggunakan beberapa kriteria yang menjadi penentuan penggunaan purposive sampling adalah karena tidak semua sampel memiliki kriteria sesuai dengan kriteria yang telah penulis tentukan. Adapun kriteria bank yang dijadikan sampel pada penelitian ini sebagai berikut:

1. BUS yang terdaftar di OJK pada periode 2014-2018

2. BUS yang telah mempublikasikan laporan tahunan pada akhir periode 31 Desember selama periode 2014 sampai dengan periode 2018

3. Adanya laporan keuangan tahunan pada BUS secara lengkap dari periode 2014 sampai dengan 2018

Berdasarkan uraian di atas maka nama-nama BUS yang terpilih sebagai sampel:

\section{Tabel 2}

\section{Sampel Penelitian}

\begin{tabular}{|c|l|}
\hline No. & \multicolumn{1}{|c|}{ Nama Bank } \\
\hline 1. & PT. Bank BCA Syariah \\
\hline 2. & PT. Bank BJB Syariah \\
\hline 3. & PT. Bank BNI Syariah \\
\hline 4. & PT. Bank BRISyariah Tbk \\
\hline 5. & PT. Bank BTPN Syariah Tbk \\
\hline 6. & PT. Bank Maybank Syariah Indonesia \\
\hline 7. & PT. Bank Mega Syariah \\
\hline 8. & PT. Bank Muamalat Indonesia Tbk \\
\hline 9. & PT. Bank Panin Dubai Syariah Tbk \\
\hline 10. & PT. Bank Syariah Bukopin \\
\hline 11. & PT. Bank Syariah Mandiri \\
\hline 12. & PT. Bank Victoria Syariah \\
\hline
\end{tabular}

Sumber: Otoritas Jasa Keuangan (OJK) [3]

Dalam penelitian ini menggunakan jenis data kuantitatif dengan dimensi data panel sebagai acuan dalam penelitian, karena data tersebut merupakan kombinasi dari data time series 
dan cross section. Sumber data yang digunakan pada penelitian ini yaitu menggunakan data sekunder. Data sekunder yang dibutuhkan tersebut merupakan data yang sudah jadi berupa laporan keuangan tahunan yang telah diaudit dan dipublikasikan oleh pihak BUS maupun OJK selaku regulator keuangan Indonesia, serta data makroekonomi yang terdiri dari inflasi dan GDP tahunan yaitu pada tahun 2014 sampai dengan tahun 2018 yang dibublikasikan oleh Bank Indonesia (BI) dan Badan Pusat Statistik (BPS) dengan cara browse dan mengunduh semua laporan tahunan yang diperlukan melalui website resmi dari setiap instansi tersebut. Teknik yang digunakan untuk pengumpulan data dalam penelitian ini adalah menggunakan teknik observasi non partisipasi. Teknik observasi merupakan salah satu teknik pengumpulan data dimana peneliti mengadakan pengamatan dan pencatatan secara sistematis terhadap objek yang diteliti, baik dalam situasi buatan yang secara khusus diadakan (laboratorium) maupun dalam situasi alamiah atau sebenarnya [30]. Sedangkan alasan menggunakan observasi non partsipasi adalah obervasi yang dilakukan dalam penelitian ini dilakukan oleh peneliti terhadap suatu objek melalui perantara yaitu dengan alat atau cara tertentu [30].

Untuk menghitung efisiensi BUS menggunakan teknik Data Envelopment Analysis (DEA), sedangkan untuk faktor-faktor yang mempengaruhi efisiensi perbankan syariah menggunakan penghitungan statistik regresi data panel dengan menggunakan bantuan program komputer software DEAP 21 dan Eviews 10.

\section{HASIL DAN PEMBAHASAN}

\section{Hasil Pengukuran Efisiensi Bank Syariah dengan Menggunakan Metode DEA}

Pengukuran efisiensi perbankan syariah dilakukan terlebih dahulu sebelum dilakukannya uji hipotesis. Untuk menilai efisiensi dalam penghitungannya, penulis menggunakan analisis DEA untuk melihat perbandingan dari beberapa UKE (Unit Kegiatan Ekonomi) dengan menggunakan input dan output tertentu. Adapun jumlah UKE dalam penelitian ini sebanyak 12 sampel BUS di Indonesia dengan periode lima tahun dari tahun 2014 sampai tahun 2018. Sebagai input dalam pengukuran efisiensi perbankan syariah menggunakan dana pihak ketiga dan biaya tenaga kerja. Sedangkan sebagai outputnya menggunakan pembiayaan dan pendapatan operasional. Selanjutnya dari data input dan output tersebut diinput ke dalam Microsoft Excel sebagai data input pengukuran DEA. Metode DEA berfungsi untuk mengukur efisiensi bank syariah dengan menggunakan software khusus yaitu DEAP versi 2.1. Hasil pengukuran ini menunjukkan efisiensi dari masing-masing bank umum syariah yang menjadi sampel penelitian, hasil perhitungan efisiensi 12 BUS melalui pendekatan DEA pada periode 2014 - 2018 disajikan pada grafik berikut. 


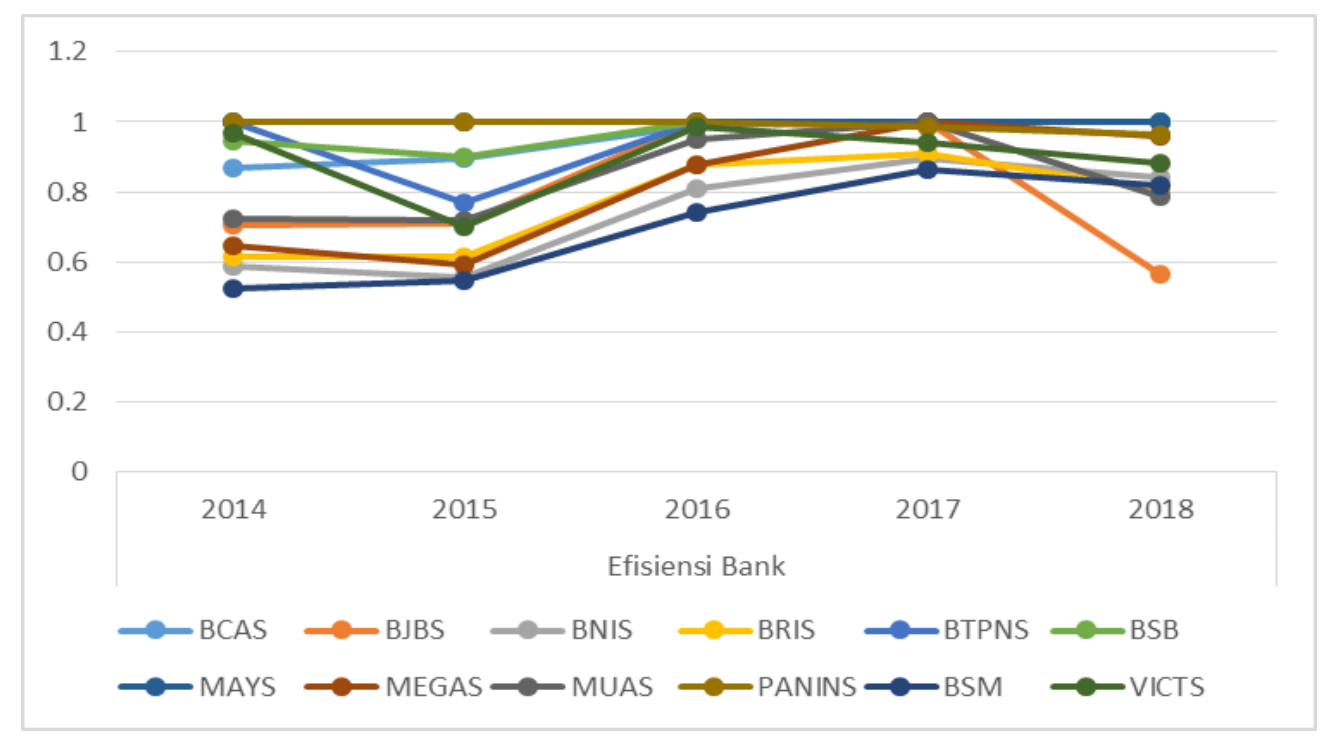

Gambar 2

Sumber: Data Diolah

Efisiensi BUS

Dari gambar 2 hasil pengukuran efisiensi menunjukkan bahwa efisiensi 12 BUS pada periode 2014-2018 menunjukkan trend yang fluktuatif yang berkisar antara 0,521-1. BUS yang mengalami kondisi efisien sepanjang periode penelitian berjumlah satu BUS, yaitu Bank Maybank Syariah. Sedangkan BUS yang memiliki nilai efisiensi terendah adalah Bank Syariah Mandiri dengan nilai rata-rata sebesar 0,6972. Walaupun demikian nilai efisiensi BUS rata-rata tidak menunjukan kenaikan atau penuruan yang sangat tajam, hanya terlihat nilai efisiensi dari Bank BJB Syariah mengalami penurunan yang cukup tinggi dari tahun 2017 ke 2018 yang semula sebesar 0,999 menjadi 0,564. Data tersebut menggambarkan bahwa selama periode 2014 sampai dengan 2018 rata-rata nilai efisiensi BUS masih berada dibawah angka 1 yang berarti bahwa efisiensi BUS di Indonesia masih belum optimal. Temuan ini sejalan dengan penelitian Pambuko [6], Permana dan Adityawarman [18], Hidayati dkk. [19], Firdaus dan Hosen [4] yang menyatakan bahwa bank syariah belum mampu beroperasi secara optimal.

\section{Hasil Analisis Regresi Data Panel}

Pemilihan metode estimasi model dilakukan dengan uji pemilihan model untuk menentukan model terbaik pada data panel, dari hasil uji tersebut terpilih model estimasi fixed effect. Untuk gambaran lebih jelasnya dapat dilihat pada tabel dibawah ini: 
Tabel 3

Hasil Uji Chow

Redundant Fixed Effects Tests

Pool: MODEL_POOL

Test cross-section fixed effects

\begin{tabular}{llcl}
\hline \hline Effects Test & Statistic & d.f. & Prob. \\
\hline \hline Cross-section F & 2.621031 & $(11,43)$ & 0.0118 \\
Cross-section Chi-square & 30.787248 & 11 & 0.0012 \\
\hline \hline
\end{tabular}

Sumber: Output Eviews Ver 10

Berdasarkan tabel 3 nilai Prob. Cross-Section Chi Square lebih kecil dari nilai 0,05 yaitu sebesar 0,0012 < 0,05, artinya H0 ditolak maka model terbaik adalah Fixed Effect.

\section{Tabel 4}

Hasil Estimasi Fixed Effect Model

Dependent Variable: EFF?

Method: Pooled Least Squares

Date: 06/27/19 Time: 14:12

Sample: 20142018

Included observations: 5

Cross-sections included: 12

Total pool (balanced) observations: 60

\begin{tabular}{|c|c|}
\hline Variable & CoefficientStd. Error t-Statistic Prob. \\
\hline $\mathrm{C}$ & $-10.188112 .660582-3.8292800 .0004$ \\
\hline FDR? & 0.4978540 .1186824 .1948500 .0001 \\
\hline NPF? & $-0.0123650 .005658-2.1853260 .0344$ \\
\hline BS? & 217.840385 .590502 .5451460 .0146 \\
\hline GDP? & $-1.3210360 .344586-3.8336880 .0004$ \\
\hline INF? & $-1.5419100 .484494-3.1825180 .0027$ \\
\hline \multicolumn{2}{|c|}{ Fixed Effects (Cross) } \\
\hline BCAS--C & -0.046977 \\
\hline BJBS--C & 0.064594 \\
\hline BNIS--C & 0.394480 \\
\hline BRIS--C & 0.345530 \\
\hline BTPNS--C & -0.191325 \\
\hline BSB--C & -0.280040 \\
\hline MAYS--C & -0.543165 \\
\hline MEGAS--C & -0.105652 \\
\hline MUAS--C & 0.406189 \\
\hline PANINS--C & -0.150897 \\
\hline BSM--C & 0.635580 \\
\hline _VICTS--C & -0.528316 \\
\hline
\end{tabular}

Sumber : Output Eviews Ver 10

Maka dari hasil estimasi dengan menggunakan model fixed effect dapat dibentuk persamaan sebagai berikut:

$\mathrm{EFF}=-10.18811+0.497854 * \mathrm{FDR}-0.012365 * \mathrm{NPF}+217.8403 * \mathrm{BS}-1.321036 * \mathrm{GDP}-$

\section{$1.541910 * \mathrm{INF}$}




\section{PEMBAHASAN}

\section{Pengaruh FDR, NPF, Bank Size, GDP, dan Inflasi terhadap Efisiensi Perbankan Syariah} Indonesia

Berdasarkan hasil pengujian uji simultan pada tabel 4.3 bahwa nilai Fhitung yang digambarkan oleh F-statistic adalah 6,710818 dengan tingkat signifikansi ditunjukan oleh nilai prob (Fstatistic) 0,0000, sedangkan hasil perolehan $F_{\text {tabel }}$ adalah 2,39, karena nilai $F_{\text {hitung }}>F_{\text {tabel }}$ $(6,710818>2,39)$, maka H0 ditolak dan Ha diterima, artinya variabel FDR, NPF, Bank Size, GDP, dan Inflasi, secara bersama-sama berpengaruh dan signifikan terhadap efisiensi perbankan syariah. Nilai adjusted R squared diperoleh sebesar 0,607643 atau 61\%, nilai ini berarti bahwa sebesar $61 \%$ perubahan variabel dependen (Y) dapat dijelaskan oleh variabel independen (X) dalam model, sedangkan sisanya sebesar 39\% dipengaruhi oleh variabel lain diluar model.

Hasil penelitian ini terjadi karena variabel FDR, NPF, Bank Size, GDP, dan Inflasi memiliki keterkaitan satu sama lain, dengan memiliki aset yang besar maka bank dapat meminimalisir biaya operasi yang tinggi sehingga dapat lebih banyak meyalurkan pembiayaan kepada nasabah dengan syarat pembiayaan yang lebih sederhana, disisi lain dengan adanya syarat pembiayaan yang lebih sederhana dapat mencegah tingginya resiko kredit yang berdampak pada tingginya rasio NPF, karena nasabah tidak akan mengalami kesulitan dalam proses pengembalian pembiayaan kepada bank, sehingga aliran dana dari bank kepada nasabah atau sebaliknya akan berjalan lancar, dan peningkatan rasio NPF pun dapat terminimalisir. Sedangkan untuk GDP dan Inflasi pihak internal bank dapat memanfaatkan aset nya yang besar untuk menciptakan produk keuangan yang baru agar nasabah tetap melakukan aktivitas perbankan walau dalam keadaan GDP yang sedang baik, inovasi produk baru juga dapat meningkatkan pertumbuhan dana pihak ketiga sehingga bank dapat meningkatkan pertumbuhan modalnya, dengan aset yang besar pun pihak bank dapat mempermudah perhitungan dalam menentukan pengurangan jumlah uang yang beredar melalui penetapan persediaan uang kas di pihak bank itu sendiri. Dari keterkaitan tersebut seluruh variabel bebas dalam penelitian ini mempengaruhi terhadap naik turunnya nilai efisiensi perbankan syariah, sehingga dapat dijadikan bahan analisis dan bahan pertimbangan kepada bank syariah di Indonesia maupun bank konvensional di Indonesia dalam membuat keputusan terhadap permasalahan efisiensi bank jika mengalami penurunan. 


\section{Pengaruh Financing to Deposit Ratio (FDR) terhadap Efisiensi Perbankan Syariah Indonesia}

Tabel 5
Hasil Uji Koefisien Determinasi $\left(\mathbf{R}^{\mathbf{2}}\right)$, dan Uji Hipotesis (Uji F
Cross-section fixed (dummy variables)

Sumber : output eviews 10

Dari hasil uji t parsial pada tabel 5 menghasilkan nilai thitung yang digambarkan pada tstatistic sebesar 4,194850 dan nilai sig. probability sebesar 0,0001. Karena nilai thitung lebih besar dari $t_{\text {tabel }}(4,194850>2,00488)$ dan nilai signifikansi $0.0001<0,05$. Maka H0 ditolak dan Ha diterima, artinya FDR berpengaruh positif dan signifikan terhadap Efisiensi Perbankan Syariah.

Jika rasio FDR mengalami peningkatan maka akan diikuti dengan meningkatnya efisiensi perbankan syariah, begitu juga jika rasio FDR mengalami penurunan maka akan diikuti pula dengan menurunnya efisiensi perbankan syariah. Hal ini terjadi karena adanya kemampuan bank dalam mengelola kegiatan operasionalnya secara produktif, sehingga banyaknya uang yang dikelola oleh pihak bank, dan bank mampu meminimalisir biaya operasi yang tinggi, yang akhirnya bank mampu memberikan lebih banyak pembiayaan kepada nasabah dengan syarat pembiayaan yang lebih sederhana, maka hal tersebut dapat meningkatkan jumlah pangsa pasar khususnya pada segmen pembiayaan dan mendorong meningkatnya profit bank itu sendiri. Dalam kondisi tersebut, bank berada dalam kategori efisien.

Hasil penelitian ini sejalan dengan penelitian yang dilakukan oleh Pambuko [6] dan Wahab [7] yang mengungkapkan bahwa FDR berpengaruh positif signifikan terhadap efisiensi bank syariah, dalam penelitiannya menjelaskan bahwa semakin besar porsi DPK yang dialokasikan untuk pembiayaan akan menyebabkan bank syariah semakin efisien dalam mengelola sumberdayanya. Lebih lanjut, hasil ini juga sesuai dengan hasil analisis DEA yang mengungkapkan bahwa salah satu penyebab ketidakefisienan bank syariah adalah kurangnya jumlah pembiayaan yang dialokasikan kepada masyarakat sehingga jika jumlah pembiayaan ditingkatkan, maka akan membuat bank semakin efisien. 


\section{Pengaruh Non Performing Financing (NPF) terhadap Efisiensi Perbankan Syariah Indonesia}

Dari hasil uji t parsial pada tabel 5 menghasilkan nilai thitung yang digambarkan pada tstatistic sebesar $-2,185326$ dan nilai sig. probability sebesar 0,0344. Karena nilai thitung lebih kecil dari $t_{\text {tabel }}(-2,185326<-2.00488)$ dan nilai signifikansi $0,0344<0,05$. Maka H0 ditolak dan Ha diterima, artinya NPF berpengaruh negatif dan signifikan terhadap Efisiensi Perbankan Syariah.

Semakin tinggi rasio NPF maka akan menyebabkan efisiensi perbankan syariah semakin rendah, begitu juga sebaliknya. Hal ini disebabkan karena tingginya penyaluran dana yang disalurkan melalui kredit atau pembiayaan yang diberikan melebihi batas wajar, maka akan meningkatkan risiko yang akan ditanggung oleh pihak bank, dan kemungkinan yang terjadi risiko kredit atau pembiayaan bermasalah akan tinggi pula, sehingga berdampak pada meningkatnya rasio NPF. NPF yang tinggi akan memperbesar biaya sehingga berpotensi terhadap kerugian bank.

Hasil penelitian ini sejalan dengan penelitian yang dilakukan oleh Firdaus dan Hosen [4] yang menunjukkan bahwa NPF memiliki pengaruh negatif dan signifikan terhadap efisiensi perbankan syariah Indonesia. Semakin besar nilai NPF pada suatu bank maka secara otomatis akan mengganggu kegiatan operasional bank, terutama dari segi likuiditas bank tersebut. Maka hal tesebut akan menyebabkan suatu bank menjadi inefisien dalam mendayagunakan seluruh sumber daya yang dimiliki. Hasil tersebut juga sejalan dengan hasil penelitian yang dilakukan oleh Wahab [7], yang menyatakan bahwa NPF berpengaruh negatif tidak signifikan terhadap efisiensi bank syariah dengan pendekatan SFA.

\section{Pengaruh Bank Size terhadap Efisiensi Perbankan Syariah Indonesia}

Dari hasil uji t parsial pada tabel 5 menghasilkan nilai thitung yang digambarkan pada tstatistic sebesar 2,545146 dan nilai sig. probability sebesar 0,0146. Karena nilai $t_{\text {hitung }}$ lebih besar dari tabel $(2,545146>2,00488)$ dan nilai signifikansi 0,0146 < 0,05. Maka H0 ditolak dan Ha diterima, artinya Bank Size berpengaruh positif dan signifikan terhadap Efisiensi Perbankan Syariah.

Semakin besar ukuran bank maka bank tersebut memiliki lebih banyak modal yang dapat digunakan untuk mengadopsi teknologi baru yang dapat meningkatkan laba dan meminimalkan biaya, dengan meningkatnya jumlah aset yang dimiliki atau semakin besarnya ukuran dari suatu bank, maka akan membuat bank tersebut menjadi lebih efisien atau mencapai efisien yang optimal. 
Hasil penelitian ini sejalan dengan penelitian yang dilakukan oleh Firdaus dan Hosen [4], Sufian dkk [8] yang menyatakan bahwa aset berpengaruh positif dan signifikan, karena dengan jumlah aset yang besar suatu perusahaan dapat lebih leluasa menjalankan kegiatan operasionalnya dan mencapai optimalisasi sumber daya yang dimilikinya. Hasil tersebut juga sejalan dengan Permana dan Adityawarman [18] yang mengungkapkan bahwa Bank Size berpengaruh secara positif dan tidak memiliki pengaruh yang signifikan terhadap efisiensi perbankan syariah.

\section{Pengaruh Gross Domestic Product (GDP) terhadap Efisiensi Perbankan Syariah Indonesia}

Dari hasil uji t parsial pada tabel 5 menghasilkan nilai thitung yang digambarkan pada tstatistic sebesar $-3,833688$ dan nilai sig. probability sebesar 0,0004. Karena nilai thitung lebih kecil dari $\mathrm{t}_{\text {tabel }}(-3,833688<-2,00488)$ dan nilai signifikansi 0,0004 < 0,05. Maka H0 ditolak dan Ha diterima, artinya GDP berpengaruh negatif dan signifikan terhadap Efisiensi Perbankan Syariah.

Semakin tinggi GDP maka akan menyebabkan efisiensi perbankan syariah menurun begitu juga sebaliknya. Hal ini disebabkan karena GDP merupakan salah satu indikator untuk mengukur pendapatan nasional, semakin besar pendapatan yang dimiliki oleh masyarakat, maka masyarakat akan menggunakan pendapatannya sendiri untuk memenuhi segala keinginan dan kebutuhannya tanpa harus melakukan pinjaman uang atau dana kepada pihak bank, dampaknya rasio FDR di industri perbankan syariah akan menurun karena pembiayaan yang disalurkan kepada masyarakat berkurang.

Hasil penelitian ini sejalan dengan hasil penelitian yang dilakukan oleh Repkova [11] yang menjelaskan bahwa pertumbuhan GDP memiliki pengaruh negatif dan signifikan, GDP yang lebih tinggi cenderung menarik investor untuk mendirikan bank baru, baik bank lokal baru atau bank asing baru, dengan demikian persaingan akan semakin tinggi. Bank yang beroperasi di negara-negara yang memiliki pertumbuhan (Produk Domestik Bruto) PDB lebih tinggi cenderung bersaing dengan bank lain yang akan menghasilkan margin laba yang lebih kompetitif. Hasil tersebut juga sejalan dengan hasil penelitian yang dilakukan oleh Batir dkk [9], Alhabshi dan Haron [28], Pambuko [6] yang menjelaskan bahwa adanya pengaruh negatif antara pertumbuhan GDP dengan efisiensi perbankan. 


\section{Pengaruh Inflasi terhadap Efisiensi Perbankan Syariah Indonesia}

Dari hasil uji t parsial pada tabel 5 menghasilkan nilai thitung yang digambarkan pada $\mathrm{t}-$ statistic sebesar $-3,182518$ dan nilai sig. probability sebesar 0,0027. Karena nilai thitung lebih kecil dari tabel $(-3,182518<-2,00488)$ dan nilai signifikansi 0,0027 < 0,05. Maka H0 ditolak dan Ha diterima, artinya Inflasi berpengaruh negatif dan signifikan terhadap Efisiensi Perbankan Syariah.

Semakin tinggi inflasi maka akan menyebabkan efisiensi perbankan syariah menjadi turun begitu juga sebaliknya. Hal ini disebabkan karena inflasi yang tinggi akan mempengaruhi keadaan ekonomi dan kinerja industri keuangan. Kenaikan harga barang dan jasa secara tidak langsung dapat meningkatkan biaya operasional sektor perbankan, yang kemudian akan menurunkan efisiensi perbankan syariah. Selain itu tingginya tingkat inflasi berdampak pada menurunnya minat masyarakat untuk menabung di bank.

Hasil penelitian ini sejalan dengan penelitian yang dilakukan oleh Alhabshi dan Haron [28] yang mengungkapkan bahwa Inflasi memiliki pengaruh yang negatif terhadap efisiensi bank, dengan kata lain tingkat inflasi yang tinggi mempengaruhi ekonomi dan kinerja industri keuangan. Kenaikan harga barang dan jasa secara tidak langsung dapat meningkatkan biaya operasional sektor perbankan, yang kemudian akan menurunkan efisiensi perbankan syariah. Hasil tersebut sejalan dengan hasil penelitian yang dilakukan oleh Batir dkk [9] dan Pambuko [6] yang menjelaskan bahwa adanya pengaruh negatif dan signifikan antara inflasi dengan efisiensi perbankan.

\section{SIMPULAN DAN SARAN}

\section{Simpulan}

Berdasarkan hasil penelitian dan pembahasan yang telah dijelaskan, maka dapat diperoleh kesimpulan sebagai berikut :

Variabel Financing to Deposit Ratio (FDR), Non Performing Financing (NPF), Bank Size (Ukuran Bank), Gross Domestic Product (GDP), dan Inflasi berpengaruh signifikan terhadap efisiensi perbankan syariah.

Variabel Financing to Deposit Ratio (FDR) berpengaruh positif dan signifikan terhadap efisiensi perbankan syariah. Tingginya efisiensi perbankan syariah dipengaruhi oleh tingginya rasio FDR, demikian sebaliknya rendahnya efisiensi perbankan syariah dipengaruhi oleh rendahnya rasio FDR. 
Variabel Non Performing Financing (NPF) berpengaruh negatif dan signifikan terhadap efisiensi perbankan syariah. Tingginya efisiensi perbankan syariah dipengaruhi oleh rendahnya rasio NPF, demikian sebaliknya rendahnya efisiensi perbankan syariah dipengaruhi oleh tingginya rasio NPF.

Variabel Bank Size (Ukuran Bank) berpengaruh positif dan signifikan terhadap efisiensi perbankan syariah. Tingginya efisiensi perbankan syariah dipengaruhi oleh besarnya ukuran bank, demikian sebaliknya rendahnya efisiensi perbankan syariah dipengaruhi oleh kecilnya ukuran bank.

Variabel Gross Domestic Product (GDP) berpengaruh negatif dan signifikan terhadap efisiensi perbankan syariah. Tingginya efisiensi perbankan syariah dipengaruhi oleh rendahnya tingkat GDP, demikian sebaliknya rendahnya efisiensi perbankan syariah dipengaruhi oleh tingginya tingkat GDP.

Variabel Inflasi berpengaruh negatif dan signifikan terhadap efisiensi perbankan syariah. Tingginya efisiensi perbankan syariah dipengaruhi oleh rendahnya tingkat inflasi, demikian sebaliknya rendahnya efisiensi perbankan syariah dipengaruhi oleh tingginya tingkat inflasi.

\section{Saran}

Berdasarkan hasil analisis dan pembahasan serta kesimpulan yang telah dikemukakan, maka penulis menyampaikan beberapa saran sebagai berikut:

Rasio FDR mencerminkan besarnya jumlah pembiayaan yang disalurkan kepada masyarakat dari dana yang telah berhasil dihimpun oleh pihak bank syariah. Bank syariah dikatakan efisien jika bank syariah mampu mengalokasikan pembiayaan yang besar kepada masyarakat atau nasabah tetapi dalam batasan yang wajar, jika bank syariah ingin memiliki efisiensi yang optimal maka bank syariah harus lebih selektif dalam memberikan pembiayaan ke beberapa sektor disarankan lebih memilih nasabah yang memiliki prospek keuntungan baik sehingga keuntungan yang diperoleh diharapkan bisa meningkat, serta diiringi dengan meningkatkan pertumbuhan dana pihak ketiga untuk menekan angka rasio FDR yang terlalu tinggi melampaui batas maksimal.

Bank syariah dikatakan efisien apabila memiliki rasio NPF yang kecil, jika bank syariah ingin memiliki efisiensi yang optimal, maka bank syariah harus melakukan pengelolaan pembiayaan dengan lebih baik seperti peningkatan kualitas pembiayaan yang disalurkan, dengan menargetkan pembiayaan tidak hanya terfokus di sektor-sektor kecil, lebih selektif dalam memberikan pembiayaan kepada nasabah, serta memberikan pembiayaan harus 
berdasarkan prinsip kehati-hatian, agar dapat meminimalisir terjadinya pembiayaan yang bermasalah.

Ukuran bank yang besar dapat dilihat dari total aset yang dimiliki oleh suatu bank. Bank syariah dikatakan efisien apabila bank syariah memiliki ukuran yang besar atau memiliki total aset yang besar. Jika bank syariah ingin memiliki efisiensi yang optimal, maka bank syariah harus melakukan peningkatan modal dengan memperhatikan kualitas aktiva yang dimiliki oleh bank syariah, dengan tetap mewaspadai peningkatan rasio NPF, selain itu bank syariah harus meningkatkan pertumbuhan dana pihak ketiga dengan cara menciptakan inovasi produk keuangan yang menarik agar semakin banyak nasabah yang menabung atau melakukan aktivitas perbankan. Bank syariah juga dapat membukakan diri menjadi go public untuk mendapatkan modal yang semakin besar.

GDP merupakan nilai barang-barang dan jasa-jasa yang diproduksikan di dalam negara tersebut dalam satu tahun tertentu. Bank syariah dikatakan efisien apabila tingkat GDP rendah. Jika bank syariah ingin memiliki efisiensi yang optimal maka bank syariah dalam menanggapi keadaan ketika GDP tinggi bank syariah harus melakukan monitoring, pengawasan yang ketat dan memberikan tindakan tegas terhadap nasabah yang kemungkinan besar dapat mengakibatkan terjadinya pembiayaan yang bermasalah.

Inflasi menunjukkan keadaan dimana harga atas barang dan jasa yang naik secara keseluruhan pada satu periode waktu tertentu. Bank syariah dikatakan efisien apabila tingkat inflasi rendah. Jika bank syariah ingin memiliki efisiensi yang optimal maka dalam menanggapi keadaan ketika inflasi sedang tinggi bank syariah harus mengurangi jumlah uang yang beredar, walaupun hal tersebut tepat dilakukan oleh bank sentral, maka bank umum syariah pun sedikitnya dapat membantu dalam mengurangi jumlah peredaran uang dengan cara menetapkan persediaan uang kas pada bank syariah itu sendiri.

\section{Keterbatasan Penelitian}

Penelitian ini dilakukan hanya melibatkan 12 Bank Umum Syariah dengan tiga faktor internal dan 2 faktor eksternal yang mempengaruhi efisiensi perbankan syariah, maka bagi peneliti selanjutnya yang tertarik untuk meneliti mengenai topik ini, disarankan untuk melakukan penambahan faktor internal seperti Capital Adequancy Ratio (CAR), Return On Asset (ROA), Net Interest Margin (NIM), Good Corporate Governance (GCG), dan faktor eksternalnya seperti nilai tukar dan yang lainnya. Selain itu dapat juga dengan menambahkan jumlah sampel dan periode penelitian, atau dengan menganalisis perbandingan kinerja efisiensi perbankan 
syariah dengan perbankan konvensional Indonesia atau perbankan syariah Indonesia dengan perbankan syariah luar negeri baik wilayah Asia Tenggara maupun secara global.

\section{DAFTAR PUSTAKA}

[1] R. Indonesia, UU Perbankan No. 10 tahun 1998. Republic of Indonesia, 1998.

[2] R. Indonesia, UU No. 21 tahun 2008. Republic of Indonesia, 2008.

[3] OJK, “Statistika Perbankan Syariah Indonesia 2014-2018,” 2019.

[4] M. F. Firdaus and M. N. Hosen, "Efisiensi bank umum syariah menggunakan pendekatan two-stage data envelopment analysis," Bull. Monet. Econ. Bank., vol. 16, no. 2, pp. 122, 2013.

[5] H. Muharam, “Analisis perbandingan efisiensi bank syariah di Indonesia dengan metode data envelopment analysis (Periode tahun 2005)," J. Ekon. dan Bisnis Islam, vol. 2, no. 3, pp. 80-166, 2007.

[6] Z. B. Pambuko, "Determinan Tingkat Efisiensi Perbankan Syariah di Indonesia: Two Stages Data Envelopment Analysis,” Cakrawala J. Stud. Islam, vol. 11, no. 2, pp. 178194, 2016.

[7] W. Wahab, “Analisis Faktor-faktor yang Mempengaruhi Efisiensi Bank Umum Syariah di Indonesia dengan Pendekatan Two Stage Stochastic Frontier Aproach (Studi Analisis di Bank Umum Syariah),” Econ. J. Ekon. Islam, vol. 6, no. 2, pp. 57-76, 2015.

[8] F. Sufian and F. Kamarudin, "Determinants of efficiency in the Malaysian banking sector: Does bank origins matter?," Intellect. Econ., vol. 10, no. 1, pp. 38-54, 2016.

[9] T. E. Batir, D. A. Volkman, and B. Gungor, "Determinants of bank efficiency in Turkey: Participation banks versus conventional banks," Borsa Istanbul Rev., vol. 17, no. 2, pp. 86-96, 2017.

[10] M. H. Akhtar, "After the financial crisis: a cost efficiency analysis of banks from Saudi Arabia,” Int. J. Islam. Middle East. Financ. Manag., 2013.

[11] I. Řepková, "Banking efficiency determinants in the Czech banking sector," Procedia Econ. Financ., vol. 23, pp. 191-196, 2015.

[12] M. C. Jensen and W. H. Meckling, "Theory of the firm: Managerial behavior, agency costs and ownership structure," J. financ. econ., vol. 3, no. 4, pp. 305-360, 1976.

[13] P. Z. Sari and E. Saraswati, "The Determinant of Banking Efficiency in Indonesia (DEA Approach)," J. Account. Bus. Educ., vol. 1, no. 2, pp. 208-229, 2017.

[14] A. Soemitra, Bank \& Lembaga Keuangan Syariah. Prenada Media, 2017. 
[15] R. Hidayat, Efisiensi perbankan syariah: teori dan praktik. 2014.

[16] D. Z. Hamidi and E. Lisnawati, "Measuring the Feasibility of Urban Transport Business Operations in the Disruption Era: A Case Study in Sukabumi City,” 2020, vol. 417, no. Icesre 2019, pp. 37-42.

[17] I. Gumilar and S. Komariah, "Pengukuran Efisiensi Kinerja dengan Metode Stochastic Frontier Approach Pada Perbankan Syariah,” 2011.

[18] F. Y. Permana and A. Adityawarman, "Analisis Faktor-faktor Yang Mempengaruhi Tingkat Efisiensi Perbankan Syariah Di Indonesia,” 2015.

[19] N. Hidayati, H. Siregar, and S. H. Pasaribu, "Determinant of efficiency of the Islamic banking in Indonesia,” Bul. Ekon. Monet. dan Perbank., vol. 20, no. 1, pp. 29-48, 2017.

[20] I. Ismail and D. Ak, Manajemen Perbankan. 2010.

[21] F. A. Dunia and W. Abdullah, Akuntansi biaya. 2012.

[22] M. Sulhan and S. Siswanto, Manajemen Bank: Konvensional dan Syariah. UIN-Maliki Press, 2008.

[23] L. Dendawijaya, Manajemen perbankan. Jakarta: Jakarta: Ghalia Indonesia, 2009.

[24] Z. A. Wangsawidjaja, Pembiayaan Bank Syariah. Jakarta: PT Gramedia Pustaka Utama, 2012.

[25] A. Murdoko Sudarmadji and L. Sularto, "Pengaruh ukuran perusahaan, profitabilitas, leverage, dan tipe kepemilikan perusahaan terhadap luas voluntary disclosure laporan keuangan tahunan,” in Seminar Ilmiah Nasional PESAT 2007, 2007.

[26] N. G. Mankiw, Principles of economics. Cengage Learning, 2014.

[27] M. Natsir, Ekonomi moneter \& kebanksentralan. Penerbit Mitra Wacana Media, 2014.

[28] S. M. S. J. Alhabshi, S. Kassim, and R. Haron, "Further Evidence on the Stability of Islamic versus Conventional Banks in selected GCC countries from 1999 to 2015," J. Islam. Financ., vol. 6, pp. 35-45, 2017.

[29] P. Sugiyono, Metodologi penelitian kuantitatif, kualitatif dan R\&D. Bandung: Alfabeta, 2017.

[30] M. Abdurrahman and S. A. Muhidin, Panduan praktis memahami penelitian. Bandung, 2011. 